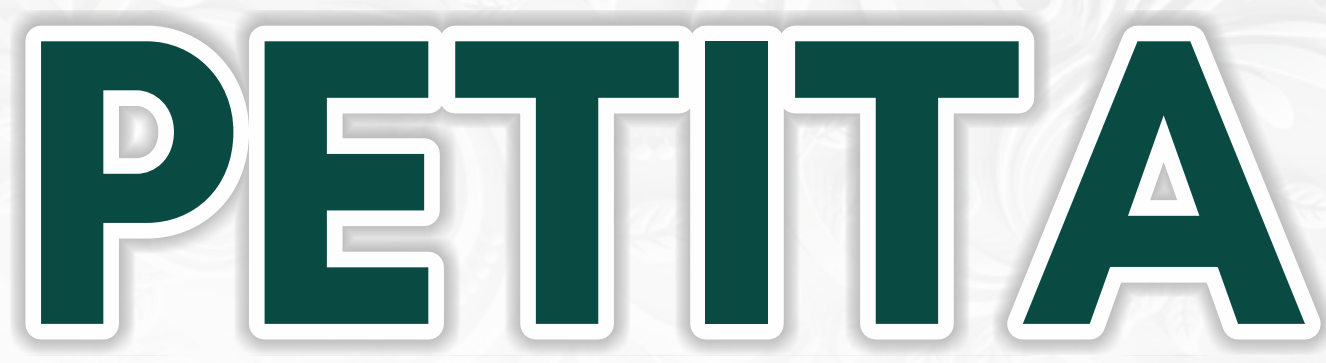

Jurnal Kajian Ilmu Hukum dan Syariah

Published By:

Lembaga Kajian Konstitusi Indonesia (LKKI)

Fakultas Syariah dan Hukum Universitas Islam Negeri (UIN) Ar-Raniry Banda Aceh Jl. Syeikh Abdul Rauf, Kopelma Darussalam Banda Aceh, Telp: 0651-7557442 Website: http://petita.ar-raniry.ac.id 


\section{Contents}

EKSISTENSI BITCOIN DALAM PERSPEKTIF MAQĀṢID AL-SYAR'ĪYAH

(Dara Lidia, Jabbar Sabil \& Syarifuddin Usman / 104-113)

TATACARA PENETAPAN BATAS TANAH DIKALANGAN MASYARAKAT KECAMATAN BAKONGAN TIMUR DITINJAU MENURUT KONSEP MAL 'UQAR

(Elida Gusmira, Saifuddin Sa'dan \& Faisal Fauzan / 114-127)

TINJAUAN HUKUM ISLAM TERHADAP SISTEM PENYELESAIAN WANPRESTASI PRODUK ARRUM DI PEGADAIAN SYARIAH ACEH BESAR

(Asdi Marni, Edi Darmawijaya \& Faisal Fauzan / 128-136)

SANKSI ADAT BAGI PELAKU KEKERASAN FISIK DITINJAU MENURUT HUKUM PIDANA ISLAM (Studi Terhadap Adat Kampung Taman Firdaus, Kecamatan Pintu Rime Gayo, Kabupaten Bener Meriah)

(Abdul Rahman, Jamhuri \& Irwansyah / 137-144)

DAMPAK PEMEKARAN DAERAH PADA PELAYANAN PUBLIK DITINJAU MENURUT SISTEM HUKUM INDONESIA

(Ali Abubakar, Sitti Mawar \& Nurdin Syah / 145-155)

MARK UP PENJUALAN HARGA TIKET BUS PADA LOKET TERMINAL BATOH DALAM PERSPEKTIF TAS'IR AL-JABAR (Studi tentang Penyimpangan Harga Dari Ketetapan Organda Banda Aceh)

(Aris Rahmaddillah / 156-169)

PROSES PENIMBANGAN IKAN DI TEMPAT PELELANGAN IKAN LAMPULO KOTA BANDA ACEH DALAM PERSPEKTIF MA'QUD 'ALAIH

(Alfata / 170-175)

SANKSI BAGI PELAKU ZINA (Perbandingan Qanun No. 6 Tahun 2014 Dan Enakmen Jenayah Syariah Negeri Selangor No. 9 Tahun 1995 Seksyen 25)

(Ali Abubakar, Badrul Munir \& Cempaka Sari Harahap / 176-200) 
PETITA: Jurnal Kajian Ilmu Hukum dan Syariah

Volume 3, Number 2, 2018

P-ISSN: 2502-8006 E-ISSN: 2549-8274

DOI: https://doi.org/10.22373/petita.v3i2.48

\title{
TINJAUAN HUKUM ISLAM TERHADAP SISTEM PENYELESAIAN WANPRESTASI PRODUK ARRUM DI PEGADAIAN SYARIAH ACEH BESAR.
}

\author{
Asdi Marni, Edi Darmawijaya \& Faisal Fauzan \\ Prodi Hukum Ekonomi Syariah \\ Universitas Islam Negeri Ar-Raniry Banda Aceh \\ e-mail: asdimarni10@gmail.com
}

\begin{abstract}
Principally, each agreement made by the parties expects the parties to conduct their performance as they should. However, there is a discrepancy between theory and practice. If one party in an agreement does not fulfil its obligations properly, then the party is said to have defaulted (breached the contract). The cases of defaults occur in the financing of ARRUM Products in Pegadaian Syariah (sharia pawnshop), the customers are delayed in repayment of the loan instalment, resulted in fines when it is due. The results of the study concluded that the customer and the sharia pawnshop determined the product financing mechanism. Defaults were subject to additional fees, especially for those who do not pay the loan instalments for three consecutive months. The sharia pawnshop had settled the defaults per sharia law by charging additional fees to the customers who can afford to pay the debts but neglect on their obligations. This process is based on the Fatwa of the National Sharia Board-MUI Number 43 of the Year 2004 concerning Compensation (Ta'widh).
\end{abstract}

Keywords: Islamic Law, Default, Pawnshop, ARRUM Products

Abstrak: Setiap perjanjian yang dibuat oleh para pihak prinsipnya adalah menghendaki agar para pihak melaksanakan prestasinya sebagaimana mestinya,akan tetapi terdapat perbedaan antara teori dan praktiknya,ketika dalam suatu perjanjian apabila salah satu pihak tidak memenuhi kewajibannya dengan semestinya, maka pihak tersebut dikatakan telah wanprestasi (Ingkar Janji). Dalam pembiayaan Produk ARRUM di pegadaian Syariahterdapat kasus wanprestasi, bentuk-bentuk wanprestasi yang dilakukan oleh nasabah berupa suatu keterlambatan dalam pembayaran angsuran pinjaman yang mengakibatkan dikenakan denda ketika telah jatuh tempo.Adapun pertanyaan dalam skripsi ini adalah Bagaimana mekanisme pembiayaan produk ARRUM di Pegadaian Syariah, Bagaimana bentuk dan Penyelesaian Wanprestasi pada transaksi Produk ARRUM di Pegadaian Syariah, Bagaimana Tinjauan Hukum Islam terhadap Penyelesaian Wanprestasi pada Produk ARRUM. Adapun metode yang digunakan dalam penelitian ini adalah deskriptif analisis. Adapun teknik pengumpulan data pada penelitian ini adalah field researchyang diperoleh melalui wawancara, serta library research yang diperoleh dari buku bacaan dan artikel yang berkenaan dengan penelitian, dan dari hasil penelitian diperoleh suatu kesimpulan bahwa mekanisme pembiayaan produk ARRUM yaitu suatu pembiayaan yang memberikan pinjaman kepada pihak nasabah yang kekurangan modal untuk keperluan Usaha, dengan jaminan BPKB kendaraan dan proses pengembalian pinjaman dengan pengangsuran setiap bulan dalam jangka waktu tertentu yang telah di tentukan oleh pihak nasabah dengan pihak pegadaian Syariah, dan bentuk-bentuk wanprestasi sehingga dikenakan biaya tambahan meliputi beberapa kasus diantaranya Tidak melakukan pembayaran angsuran pinjaman sampai pada saat jatuh tempo perbulannya, Tidak melaksanakan pembayaran angsuran pinjaman selama 3 bulan secara berturut-turut. Sementara proses penyelesaian wanprestasi yang dilakukan oleh 
pihak pegadaian Syariah sudah sesuai dengan hukum Islam dimana pihak pegadaian memberikan biaya tambahan kepada nasabah yang mampu untuk membayar hutang tetapi melalaikan kewajibannya, yang sesuai dengan Fatwa Dewan Syariah Nasional-MUI No. 43 tahun 2004 tentang Ganti Rugi (Ta'widh).

\section{Kata Kunci: Hukum Islam, Wanprestasi, Pegadaian, Produk ARRUM}

\section{Pendahuluan}

Islam adalah agama yang menjadi rahmat bagi alam semesta. Oleh karenanya sifat dari ajaran Islam adalah komprehensif dan universal. Semua aspek kehidupan manusia tidak luput dari aturan Islam, termasuk di sini mengenai hubungan manusia dengan manusia salah satunya dalam melakukan transaksi ekonomi. Kegiatan ekonomi yang dilakukan sudah seharusnya mendasarkan pada kaidah-kaidah hukum, dan hukum yang dimaksud di sini adalah hukum ekonomi Islam. ${ }^{1}$

Perkembangan peradaban manusia menimbulkan adanya perkembangan dan peningkatan kebutuhan dan keinginan manusia terutama dalam bidang ekonomi yang saat ini sedang mendapatkan perhatian dan sorotan yang tajam dari berbagai kalangan, baik pemerintahan, lembaga keuangan, praktisi bisnis, akademisi, dan umat Islam khususnya, yaitu ekonomi syariah.

Dengan adanya perkembangan dan peningkatan tersebut maka Pemerintah mulai mendirikan dan mengembangkan Lembaga Keuangan yang berdasarkan prinsip syariah di Indonesia. Salah satu yang termasuk dalam lembaga keuangan syariah (LKS) yaitu pegadaian syariah yang menjalankan kegiatan usahanya dengan prinsip-prinsip syariah.

Pegadaian Syariah tumbuh dan berkembang karena dalam realitanya dibutuhkan untuk membantu perekonomian masyarakat, baik muslim maupun non muslim. Bahkan mendapat dukungan yang cukup tinggi dari perkumpulan masyarakat ekonomi. Konsep operasi Pegadaian Syariah mengacu pada sistem administrasi modern yaitu asas rasionalitas, efesiensi dan efektifitas yang di selaraskan dengan nilai Islam.

Pada Pegadaian syariah terdapat beberapa Pembiayaan, salah satu diantaranya adalah produk ARRUM (Ar-Rahn Usaha Mikro). Untuk mendapatkan Pembiayaan ARRUM, salah satu syarat yang harus dipenuhi dan yang menjadi syarat utamanya yaitu surat BPKB dan dengan melengkapi syarat-syarat lainnya. Setelah melengkapi syarat-syarat tersebut barulah pihak pegadaian memberikan pinjaman kepada pihak nasabah, dan pengembalian pinjaman dilakukan dengan cara angsuran atau cicilan dalam setiap bulannya sesuai dengan kesepakatan.

Oleh karena itu, dalam proses pengangsuran pembayaran pinjaman oleh nasabah kepada pihak pegadaian, terdapat nasabah yang melakukan keterlambatan dan tidak memenuhi prestasinya atau nasabah tersebut melakukan Wanprestasi. Wanprestasi yang biasanya dilakukan oleh pihak nasabah yaitu terlambat dalam membayar angsuran selama satu bulan atau lebih. Dan dengan adanya nasabah yang wanprestasi maka pihak pegadaian mengambil tindakan dan langkah-langkah untuk menyelesaikan wanprestasi tersebut, salah satunya yaitu pihak nasabah harus membayar biaya tambahan (ganti rugi) atas ketelambatan pengangsuran pembayaran pinjaman kredit. Ganti rugi tersebut harus dibayar perbulan apabila nasabah tiap bulan melakukan wanprestasi dan tergantung berapa bulan pihak nasabah melakukan keterlambatan. Biaya tambahan (Ganti rugi) yang diterapkan di pegadaian syariah merupakan salah satu bentuk tindakan yang memberatkan pihak nasabah, Selain harus mengembalikan modal pokok yang dipinjamkan, tetapi pihak nasabah juga harus membayar biaya tambahan (ganti rugi) yang

1 Burhanuddin Susanto, Hukum Perbankan Syariah Di Indonesia (UII Perss 2008), hlm. 2. 
berkisar $4 \%$ perbulan, akibat dari wanprestasi dalam membayar angsuran pada setiap keterlambatan perbulannya. Oleh karena itu, maka peneliti bermaksud untuk mengkaji mengenai bagaimana tinjauan hukum Islam terhadap sistem penyelesaian wanprestasi produk ARRUM (Ar-Rahn Usaha Mikro) di pegadaian Syariah Aceh Besar.

\section{Landasan Teori}

\section{Pengertian dan Dasar Hukum Rahn(Gadai)}

Menurut bahasanya, (dalam bahasa Arab) Rahn adalah Tetap dan Lestari, seperti juga dinamai Al-Habsu, artinya penahanan. Adapun dalam pengertian Syara', ia berarti: menjadikan barang yang mempunyai nilai harta menurut pandangan syara' sebagai jaminan hutang, hingga orang yang bersangkutan boleh mengambil sebagian (manfaat) barang itu. ${ }^{2}$ Jadi, definisi $A r-R a h n$ secara istilah adalah menjamin hutang dengan barang (suatu benda) yang memungkinkan hutang dapat dibayar dengannya atau dari harganya. ${ }^{3}$

Dasar hukum gadai dalam Al-Qur'an adalah firman Allah SWT dalam QS. Al-baqarah ayat 283:

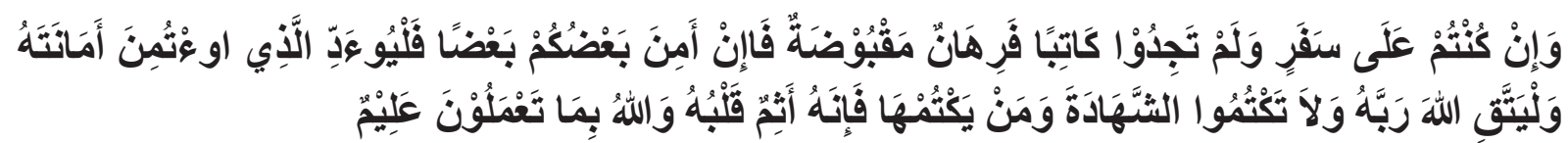

Artinya:" Jika kamu dalam perjalanan (dan bermuamalah tidak secara tunai) sedang kamu tidak memperoleh seorang penulis maka hendaklah ada barang tanggungan yang dipegang (oleh yang berpiutang). Akan tetapi ada sebagian kamu memercayai sebagian yang lain, maka hendaklah yang dipercayai itu menunaikan amanatnya (utangnya). Dan hendaklah ia bertakwa kepada Allah Tuhannya, dan janganlah kamu(para saksi) menyembunyikan persaksian. Dan barang siapa yang mnyembunyikannya, maka sesungguhnya ia adalah orang yang berdosa hatinya dan Allah Maha mengetahui apa yang kamu kerjakan.” (Q.S Al-Baqarah, ayat 283).

\section{Fatwa DSN tentang Rahn}

Menurut Fatwa DSN-MUI No. 25/DSN-MUI/lll/2002 GADAI Syariah harus memenuhi ketentuan umum berikut:

1. Murtahin (penerima barang) mempunyai hak untuk menahan Marhun (barang) sampai semua hutang Rahin (yang menyerahkan barang) dilunasi.

2. Marhun dan manfaatnya tetap menjadi milik Rahin. Pada prinsipnya, Marhun tidak boleh dimanfaatkan oleh Murtahin kecuali seizin Rahin, dengan tidak mengurangi nilai Marhun dan pemanfaatannya itu sekedar pengganti biaya pemeliharaan dan perawatannya.

3. Pemeliharaan dan penyimpanan Marhun pada dasarnya menjadi kewajiban Rahin, namun dapat dilakukan juga oleh Murtahin, sedangkan biaya dan pemeliharaan penyimpanan tetap menjadi kewajiban Rahin.

4. Besar biaya pemeliharaan dan penyimpanan Marhun tidak boleh ditentukan berdasarkan jumlah pinjaman.

5. Penjualan Marhun.

a. Apabila jatuh tempo, Murtahin harus memperingatkan Rahin untuk segera

$2 \quad$ Sayyid Sabiq, Fikih Sunnah (Pt Alma'Arif 1987), hlm. 150.

3 Minhāj al-Muslim Abu Bakar Jabir al-Jazairi, Minhajul Muslim: Pedoman Hidup Seorang Muslim (Ummul Qura 2014), hlm. 663; Lebih lanjut mengenai akad Rahn dalam praktek, sila rujuk, Edi Susilo, 'Shariah Compliance Akad Rahn Lembaga Keuangan Mikro Syariah (Studi Kasus BMT Mitra Muamalah Jepara)' (2017) 4 IQTISHADIA: Jurnal Ekonomi \& Perbankan Syariah 120 <http://ejournal.stainpamekasan. ac.id/index.php/iqtishadia/article/view/1159>.. 
melunasi hutangnya.

b. Apabila Rahin tetap tidak dapat melunasi hutangnya, maka Marhun dijual paksa/dieksekusi melalui lelang sesuai syariah.

c. Hasil penjualan Marhun digunakan untuk melunasi hutang, biaya pemeliharaan dan penyimpanan yang belum dibayar serta biaya penjualan.

d. Kelebihan hasil penjualan menjadi milik Rahin dan kekurangannya menjadi kewajiban Rahin. ${ }^{4}$

\section{Pengertian dan Dasar Hukum Qardh (Utang Piutang)}

Qardh (utang piutang) adalah suatu akad antara dua pihak, dimana pihak pertama memberikan uang atau barang kepada pihak kedua untuk dimanfaatkan dengan ketentuan bahwa uang atau barang tersebut harus dikembalikan persis seperti yang ia terima dari pihak pertama. ${ }^{5}$

Dasar hukum Qardh (Hutang Piutang) dalam Al-Qur'an adalah firman Allah SWT dalam QS. Al-baqarah ayat 245:

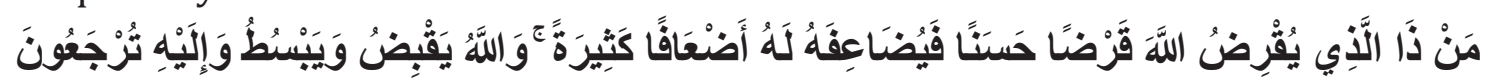

Artinya: "siapakah yang mau memberi pinjaman kepada Allah, Pinjaman yang baik (menafkahkan hartanya di jalan Allah), maka Allah akan melipatgandakan pembayaran kepadanya dengan lipat ganda yang banyak. Dan Allah menyempitkan dan melapangkan (rezeki) dan kepada-Nyalah kamu dikembalikan,"(QS. Albaqarah (2): 245).

\section{Konsep Hutang pada Ketidakmampuan Pembayaran Hutang Oleh Muqtarid (Penerima Utang).}

Akad hutang dimaksudkan untuk mengasihi manusia, menolong mereka dalam menghadapi berbagai urusan, dan memudahkan sarana-sarana kehidupan. Akad memberi hutang bukan sarana untuk memperoleh penghasilan dan bukan pula untuk mengeksploitasi orang lain. Oleh karena itu, yang berhutang tidak boleh mengembalikan kepada yang memberi hutang kecuali yang dipinjamnya atau yang serupa dengannya. Hal tersebut sesuai dengan kaedah fiqih yang mengatakan, "Setiap Piutang yang mendatangkan manfaat adalah riba."

Dalam surah Al-baqarah ayat 280 Allah SWT, yang artinya : "Dan jika (orang berutang itu) dalam kesulitan, maka berilah tenggang waktu sampai dia memperoleh kelapangan. Dan jika kamu menyedekahkan, itu lebih baik bagimu, jika kamu mengetahui." (Al-Baqarah \{2\}: 280).

Diriwayatkan pula dari Ka'ab bin Umar bahwa Rasullullah SAW, bersabda:

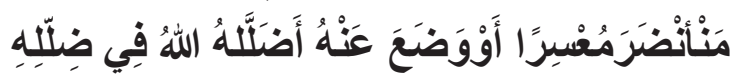

Artinya: "barangsiapa memberikan penangguhan utang kepada orang yang kesusahan atau membebaskan (sebagian atau semua) utangnya, Allah akan menaunginya dengan naungannya-Nya." (H.R. Muslim). ${ }^{7}$

Jika dalam hutang piutang ada syarat yang menguntungkan pihak pemberi hutang, maka termasuk kategori permintaan ganti. Jika masuk ke dalam kategori ganti, maka mengandung riba Al-fadl (tambahan) dan riba Nasiah (penundaan). ${ }^{8}$

$4 \quad$ Andri Soemitra, Bank Dan Lembaga Keuangan Syariah (Kencana 2009), 390-391.

$5 \quad$ Ahmad Wardi Muslich, Fiqh Muamalat (Amzah 2015), hlm. 273-274.

6 Sayyid Sabiq (n 2), hlm. 126.

$7 \quad$ Ibid, hlm. 347.

8 Muhammad Bin Shalih Al-Utsaimin, Halal Dan Haram Dalam Islam (Ummul Qura 2017), hlm 463. 
Dan apabila dalam akad Qardh mencantumkan syarat pembayaran yang melebihi pokok pinjaman (ziyadah), praktik tersebut mengandung riba. Hal itu sesuai dengan hadist, "setiap utang putangyang mendatangkan suatu keuntungan itu merupakan riba." pinjaman (Qardh) dengan tujuan apapun tidak dibolehkan, baik untuk berdagang, membeli rumah, pabrik dan sejenisnya. Sebab bunga tersebut adalah riba dan riba hukumnya haram. ${ }^{10}$

\section{Metode Penelitian}

Pada penelitian ini, peneliti menggunakan jenis penelitian kualitatif, yaitu suatu jenis penelitian yang bertujuan untuk memahami suatu fenomena dalam konteks sosial secara alamiah dengan mengedepankan proses interaksi komunikasi yang mendalam antara peneliti dengan fenomena yang diteliti. ${ }^{11}$ Penelitian ini bersifat deskriptif analisis. Deskriptif adalah sebuah penelitian yang menggambarkan suatu peristiwa pada masa sekarang, sedangkan analisis adalah menganalisa fenomena yang terjadi. Jadi, deskriptif analisis yakni sebuah penelitian yang akurat mengandung gambaran secara sistematis dan aktual terhadap fakta serta kaitannya dengan fenomena yang ada. Sumber data dalam penelitian ini dapat diperoleh melalui penelitian lapangan (Field Research) dengan proses wawancara dan studi dokumentasi, serta penelitian kepustakaan (library research) yang diperoleh melalui buku-buku. Seluruh data penelitian yang telah diperoleh, diolah menjadi suatu pembahasan untuk menjawab persoalan yang ada dengan didukung oleh teori-teori yang telah dipelajari.

\section{Hasil Penelitian Dan Pembahasan \\ Produk ARRUM (Ar-Rahn Untuk Usaha Mikro), Bentuk dan Mekanisme Penyelesaian Wanprestasi Nasabah pada Produk ARRUM (Ar-Rahn Usaha Mikro) di Pegadaian Syariah Aceh Besar.}

Produk ARRUM merupakan skim pembiayaan berbasis Syariah bagi para pengusaha mikro untuk keperluan usaha yang dikeluarkan pada tahun 2008. ${ }^{12}$ Tujuan Pegadaian Syariah menerbitkan produk ARRUM adalah untuk membantu para Pengusaha mikro yang telah berjalan minimal satu tahun yang sedang kekurangan modal atau dalam pengembangan usaha dengan cara memberikan pinjaman atau pembiayaan.

Di pegadaian Syariah Aceh Besar, Pembiayaan ARRUM berjumlah 380 orang dalam 3 tahun terakhir dari kategori usaha penjual kelontong, laundry, warung nasi, fotocopy, kafe, bengkel, home industri, pakan ayam, pangkas, isi ulang, penjual kelapa, penjual ponsel, dan lain sebagainya. Dari jumlah tersebut, sekitar 230 orang nasabah yang meminjam pinjaman dalam jumlah 10.000 sampai dengan 20.000.000, sekitar 150 orang meminjam pinjaman dalam jumlah 20.000.000 sampai dengan $200.000 .000 .^{13}$

Pada dasarnya, dalam produk ARRUM (Ar-Rahn Untuk Usaha Mikro) ini dikarenakan ada sebagian nasabah yang mengalami kerugian dalam usahanya pada saat nasabah masih dalam proses pembayaran pelunasan pinjaman. Dan ada juga nasabah yang memang mampu atau lalai dalam melunasi pembayaran pinjaman, dikarenakan si nasabah menggunakan uang yang di pinjamnya dari pegadaian di pergunakan untuk hal-hal yang lain. Dengan demikian, ketika pada saatnya jatuh tempo maka terjadilah wanprestasi.

$9 \quad$ Wahbah Zuhaili, Fiqh Imam Syafi'i (Almahira 2008), hlm. 21.

10 Ash-Shiddiq Abdurrahman Al-Gharyani, Fatwa-Fatwa Muamalah Kontemporer (Pustaka Progressif 2004), hlm. 214-215.

11 Haris Herdiansyah, Metode Penelitian Kualitatif Untuk Ilmu-Ilmu Sosial (Salemba Humanika 2012), hlm. 10.

12 http://Ettaserang.Blogspot.Com/2012/03/Gadai-Ar-Rum-Ar-Rahn-Untuk-Usaha-Mikro.Html/ M\%3D1\&hl=id-ID'.

13 'Data Pegadaian Syariah Cabang Keutapang, Aceh Besar'. 
Berdasarkan hasil penelitian, pada pembiayaan produk ARRUM lebih kurang terdapat 80 orang nasabah yang wanprestasi dalam 3 tahun terakhir. Adapun bentuk-bentuk wanprestasi yang dikenakan biaya tambahan pada peminjaman dana produk Arrum (ArRahn Untuk Usaha Mikro) adalah sebagai berikut:

1. Tidak melakukan pembayaran sampai pada saat jatuh tempo perbulannya.

Mengenai wanprestasi seperti tidak melakukan pembayaran sampai saat jatuh tempo merupakan hal yang sering dilakukan oleh nasabah dalam setiap bulannya. Nasabah yang melakukan wanprestasi dalam setiap bulannya terdapat 60 orang nasabah dalam 3 tahun terakhir yaitu dari tahun 2016-2018. ${ }^{14}$ Pada dasarnya, nasabah yang banyak melakukan wanprestasi pada setiap bulannya merupakan nasabah yang melalaikan kewajibannya padahal pihak nasabah tersebut mampu untuk membayar angsuran, sehingga nasabah tersebut dikatakan wanprestasi.

Kebijakan yang dilakukan oleh pihak pegadaian dalam menangani wanprestasi tersebut, yaitu memberi peringatan kepada pihak nasabah dengan cara menghubungi pihak nasabah agar segera melakukan pelunasan pembayaran pinjaman. Dan setiap nasabah yang melakukan penunggakan atau wanprestasi tersebut dikenakan biaya tambahan (ganti rugi) karena keterlambatan setiap bulannya. Dan pembayaran biaya tambahan tersebut berkisar $4 \%$ setiap bulannya.

2. Tidak melaksanakan pembayaran selama 3 bulan secara berturut-turut

Mengenai penunggakan pembayaran selama tiga bulan secara berturut-turut, Nasabah yang melakukan wanprestasi 3 bulan secara berturut-turut lebih kurang terdapat 20 orang nasabah dalam 3 tahun terakhir. ${ }^{15}$ Pihak pegadaian melakukan kebijakan pertama dengan memberi peringatan atau pemberitahuan kepada pihak nasabah. Peringatan tersebut berupa pihak pegadaian menghubungi pihak nasabah, supaya segera menunaikan kewajibannya. Dengan memberi pilihan kepada nasabah untuk melunasi satu bulan terlebih dahulu yang sudah tertunggak, apabila rahin memang tidak mampu lagi untuk melunasi hutangnya, maka pihak pegadaian akan melakukan pelelangan barang jaminan untuk melunasi hutang nasabah kepada pihak pegadaian. Apabila hasil dari pelelangan barang jaminan tersebut tidak mencukupi untuk pelunasan pinjaman, maka selebihnya di tanggung oleh pihak nasabah, dan apabila terdapat kelebihan akan dikembalikan kepada pihak nasabah. Lelang dilakukan setelah dikonfirmasi kepada nasabah, dan penarikan barang jaminan tersebut atas izin pihak nasabah, karena pihak nasabah tidak mampu lagi untuk melunasi angsuran pinjaman. Karena sebelum pelelangan berlangsung pihak pegadaian Syariah telah memberikan solusi kepada pihak nasabah, barang jaminan tersebut ingin ditebus atau dilelang untuk pelunasan pinjaman.

\section{Faktor penyebab terjadinya Wanprestasi pada Pegadaian Syariah Aceh Besar.}

Secara umum terdapat dua faktor yang menyebabkan nasabah wanprestasi sehingga terjadi tunggakan terhadap pelunasan pinjaman, ${ }^{16}$ yaitu:

14 Ibid.

15 Ibid.

16 Terkait faktor yang menyebabkan nasabah wanprestasi, coba bandingkan dengan beberapa kasus lainnya, lihat dalam Taufiq Akbar, Wanprestasi Pada Aqad Ijarah Dan Mekanisme Penyelesaian Pada Baitul Baznas Madani Banda Aceh (Fakultas Syariah, IAIN Ar-Raniry 2010); Ahmad Maulidi Zen, 'Penyelesaian Wanprestasi Dalam Kredit Kepemilikan Rumah (KPR) Dengan Akad Murābahah Studi Kasus Di Bank Tabungan Negara Syariah Surabaya' (2017) 23 Intizar 55 <http://jurnal.radenfatah. ac.id/index.php/intizar/article/view/1317>; Mahfud Perdana, Afrilian, Dahlan, 'Penyelesaian Wanprestasi Dalam Perjanjian Jual Beli Melalui Media Elektronik' [2014] Jurnal Ilmu Hukum; Nurul Ariy Khaeruddin, 'Wanprestasi Dan Model Penyelesaiannya Di LKMS (Studi Pada Lembaga KSPS BMT 
1. Faktor Internal.

Faktor ini merupakan faktor yang berasal dari nasabah debitur itu sendiri yaitu nasabah dengan sengaja tidak ingin membayar tagihannya yang telah ditentukan oleh pihak Pegadaian Syariah. Disebabkan nasabah sewaktu melakukan pinjaman dengan tujuan untuk keperluan hal yang lain dan bukan digunakan untuk modal usaha.

\section{Faktor Eksternal}

Faktor Eksternal merupakan faktor di luar kesalahan debitur. Dalam faktor ini nasabah debitur secara tidak sengaja melakukan wanprestasi yang diakibatkan oleh keadaan memaksa atau force meujer. Keadaan ini tidak dapat diprediksi baik oleh pihak pegadaian Syariah selaku pemberi pijaman hutang dan penerima pinjaman. Di mana keadaan ini timbul diluar kekuasaan si berhutang dan keadaan yang timbul itu juga berupa suatu keadaan yang tidak dapat diketahui pada waktu perjanjian dibuat. ${ }^{17}$ Dan dimana suatu keadaan si debitur mau membayar kewajibannya tetapi debitur mengalami kerugian dalam usahanya atau mengalami musibah seperti bencana alam atau meninggal dunia.

\section{Tinjauan Hukum Islam terhadap Sistem Penyelesaian Wanprestasi pada Produk Arrum (Ar-Rahn Usaha Mikro) di Pegadaian Syariah Aceh Besar.}

Adapun cara penyelesaian yang dilakukan pihak Pegadaian Syariah terhadap wanprestasi dalam pelunasan pinjaman dalam Produk ARRUM (Ar-Rahn Untuk Usaha Mikro) adalah dengan berpedoman pada hukum Islam atau fiqh muamalah, di dalam fiqh muamalah tidak ditemukan kata wanprestasi melainkan ingkar janji yang merupakan salah satu yang terjadi dalam pelaksanaan aqad, apabila salah satu pihak yang melakukan khianat dan telah terbukti baik itu secara tertulis maupun secara lisan terhadap apa yang telah diperjanjikan maka orang tersebut telah melakukan wanprestasi (ingkar janji) sehingga perjanjian tersebut dapat dibatalkan oleh para pihak yang merasa dirugikan tersebut.

Begitu halnya dalam perjanjian peminjaman uang antara pihak Pegadaian Syariah dengan nasabah. Seorang nasabah yang telah mengajukan permohonan peminjaman uang telah membuat perjanjian atau lebih tepatnya dikatakan telah berjanji untuk membayar pelunasan pinjaman tepat waktu dan sesuai dengan yang telah diperjanjikan, maka dalam hal ini tidak boleh dilanggar, akan tetapi harus saling menghormati antara pihak yang membuat janji tersebut agar tidak terjadi perselisihan di kemudian hari.

Akan tetapi suatu perjanjian/ perikatan diikat oleh suatu syarat dan rukun yang telah disepakati sebelumnya. Suatu perjanjian kadang kala didasari oleh batas waktu yang telah ditentukan pada awal perjanjian, apabila telah selesai waktu yang telah ditentukan terhadap suatu perjanjian, maka perjanjian tersebut akan batal dan berakhir. ${ }^{18}$

berdasarkan hal ini islam mewajibkan setiap akad transaksi muamalah yang dilakukan oleh kedua belah pihak hendaklah jelas baik secara lisan maupun tulisan serta konsekuensi yang diterima bagi yang melalaikannya sehingga akad tersebut tidak dilanggar, sebagaimana firman Allah dalam surat Al-Maidah ayat :1 yang berbunyi: ${ }^{19}$

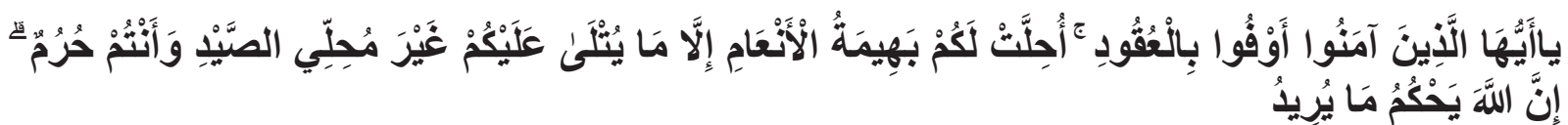

Bina Ummat Sejahtera)' [2015] Serambi Hukum.

'Hasil Wawancara Dengan M. Raul Putra, Analis Kredit Pada Pegadaian Syariah Aceh Besar Tanggal 31 Mei 2018, Di Aceh Besar.'

18 Suhrawardi K Lubis Chairuman Pasaribu, Hukum Perjanjian (Sinar Grafika 2004), hlm. 2.

19 Taufiq Akbar, Wanprestasi Pada Aqad Ijarah Dan Mekanisme Penyelesaian Pada Baitul Baznas Madani Banda Aceh (Fakultas Syariah, IAIN Ar-Raniry 2010), hlm. 63. 
Artinya: "Hai orang-orang yang beriman, penuhilah aqad-aqad itu. Dihalalkan bagimu binatang ternak, kecuali yang akan dibacakan kepadamu. (Yang demikian itu) dengan tidak menghalalkan berburu ketika kamu sedang mengerjakan haji. Sesungguhnya Allah menetapkan hukum-hukum menurut yang dikehendaki-Nya". (Q.S Al-Maidah ayat: 1)

Berdasarkan hasil penelitian peneliti bahwa pihak pegadaian Syariah Aceh besar memberikan denda kepada pihak nasabah yang menunggak dari tanggal jatuh tempo. Besar biaya tambahan yang diberikan berkisar 4\% untuk setiap bulan atas keterlambatan nasabah apabila nasabah tidak membayar pada saat jatuh tempo, nasabah yang menunggak pembayaran tersebut merupakan nasabah yang melalaikan kewajibannya dalam melakukan angsuran pinjaman. Sanksi dalam bentuk ini merupakan salah satu alternatif / kebijakan yang digunakan sebagai sarana motivasi dan memperkuat kedisiplinan bagi nasabah Produk ARRUM khususnya pelanggan yang dengan sengaja tidak mau membayar pelunasan cicilan pinjaman.

Hal ini berdasarkan berdasarkan Fatwa Dewan Syariah Nasional-MUI No. 17 tahun 2000 tentang sanksi atau nasabah yang menunda-nunda pembayaran. ${ }^{20}$ Yang berkenaan dengan sanksi atas nasabah mampu yang menunda-nunda pembayaran Fatwa Dewan Syariah Nasional No. 43 tahun 2004 tentang ganti rugi.

\section{Kesimpulan}

Wanprestasi merupakan sebagai suatu bentuk tidak mematuhi atau lalai melaksanakan kewajiban sebagaimana yang ditentukan dalam perjanjian yang dibuat antara kreditur dan debitur. Jadi wanprestasi merupakan ketentuan perjanjian yang dilanggar karena berbagai hal yang dapat mengakibatkan salah satu pihak merasa sangat dirugikan atas kelalaian atau tidak mematuhi oleh pihak yang lain.

Berdasarkan penelitian nasabah yang wanprestasi akan dikenakan biaya tambahan atau ganti rugi berkisar 4\%, dan pemberian biaya tambahan pada nasabah yang wanprestasi sudah sesuai dengan ketentuan-ketentuan hukum islam. Di mana hal tersebut telah tercantum dalam Fatwa Dewan Syariah Nasional-MUI No. 17 tahun 2000 tentang sanksi atau nasabah yang menunda-nunda pembayaran.Yang berkenaan dengan sanksi atas nasabah mampu yang menunda-nunda pembayaran Fatwa Dewan Syariah Nasional No. 43 tahun 2004 tentang ganti rugi.

\section{Daftar Pustaka}

Abu Bakar Jabir al-Jazairi M al-M, Minhajul Muslim: Pedoman Hidup Seorang Muslim (Ummul Qura 2014)

Ahmad Wardi Muslich, Fiqh Muamalat (Amzah 2015)

Andri Soemitra, Bank Dan Lembaga Keuangan Syariah (Kencana 2009)

Ariy Khaeruddin N, 'Wanprestasi Dan Model Penyelesaiannya Di LKMS (Studi Pada Lembaga KSPS BMT Bina Ummat Sejahtera)' [2015] Serambi Hukum

Ash-Shiddiq Abdurrahman Al-Gharyani, Fatwa-Fatwa Muamalah Kontemporer (Pustaka Progressif 2004)

Burhanuddin Susanto, Hukum Perbankan Syariah Di Indonesia (UII Perss 2008)

20 Perpustakaan Nasional Katalog dalam terbitan (KTD), Himpunan Undang-Undang Dan Peraturan Pemerintah Tentang Ekonomi Syariah, Dilengkapi 44 Fatwa DSN MUI Tentang Produk Perbankan Syariah (Pustaka Zeedny 2009), hlm. 174. 
Chairuman Pasaribu SKL, Hukum Perjanjian (Sinar Grafika 2004)

'Data Pegadaian Syariah Cabang Keutapang, Aceh Besar'

'http://Ettaserang.Blogspot.Com/2012/03/Gadai-Ar-Rum-Ar-Rahn-Untuk-Usaha-Mikro. Html/M\%3D1\&hl=id-ID'

Haris Herdiansyah, Metode Penelitian KualitatifUntuk Ilmu-Ilmu Sosial (Salemba Humanika 2012)

'Hasil Wawancara Dengan M. Raul Putra, Analis Kredit Pada Pegadaian Syariah Aceh Besar Tanggal 31 Mei 2018, Di Aceh Besar.'

Muhammad Bin Shalih Al-Utsaimin, Halal Dan Haram Dalam Islam (Ummul Qura 2017)

Perdana, Afrilian, Dahlan M, 'Penyelesaian Wanprestasi Dalam Perjanjian Jual Beli Melalui Media Elektronik' [2014] Jurnal Ilmu Hukum

Perpustakaan Nasional Katalog dalam terbitan (KTD), Himpunan Undang-Undang Dan Peraturan Pemerintah Tentang Ekonomi Syariah, Dilengkapi 44 Fatwa DSN MUI Tentang Produk Perbankan Syariah (Pustaka Zeedny 2009)

Sayyid Sabiq, Fikih Sunnah (Pt Alma’Arif 1987)

Susilo E, 'Shariah Compliance Akad Rahn Lembaga Keuangan Mikro Syariah (Studi Kasus BMT Mitra Muamalah Jepara)’ (2017) 4 IQTISHADIA: Jurnal Ekonomi \& Perbankan Syariah $120<$ http://ejournal.stainpamekasan.ac.id/index.php/iqtishadia/article/ view/1159>

Taufiq Akbar, Wanprestasi Pada Aqad Ijarah Dan Mekanisme Penyelesaian Pada Baitul

Baznas Madani Banda Aceh (Fakultas Syariah, IAIN Ar-Raniry 2010)

Wahbah Zuhaili, Fiqh Imam Syafi'i (Almahira 2008)

Zen AM, 'Penyelesaian Wanprestasi Dalam Kredit Kepemilikan Rumah (KPR) Dengan Akad Murābaḥah Studi Kasus Di Bank Tabungan Negara Syariah Surabaya' (2017) 23 Intizar 55 <http://jurnal.radenfatah.ac.id/index.php/intizar/article/view/1317> 